\section{Thyme essential oil for sheep: effect on rumen fermentation, nutrient digestibility, nitrogen metabolism, and growth}

[Óleo essencial de tomilho para ovinos: efeito na fermentação ruminal, na digestibilidade dos nutrientes, no metabolismo de nitrogênio e no crescimento]

\author{
A.D.B. Ribeiro ${ }^{1}$, M.V.C. Ferraz Junior ${ }^{2}$, D.M. Polizel ${ }^{1,3}$, A.A. Miszura ${ }^{1}$, \\ L.G.M. Gobato ${ }^{1}$, J.P.R. Barroso ${ }^{1}$, I. Susin ${ }^{3}$, A.V. Pires ${ }^{1,3}$ \\ ${ }^{1}$ Escola Superior de Agricultura "Luiz de Queiroz" - Universidade de \\ São Paulo - Piracicaba, SP \\ ${ }^{2}$ Universidade Federal do Amazonas - Parintins, AM \\ ${ }^{3}$ Faculdade de Medicina Veterinária e Zootecnia - Universidade de \\ São Paulo - Pirassununga, SP
}

L.G.M. Gobato

https://orcid.org/0000-0002-5449-5542 J.P.R. Barroso

https://orcid.org/0000-0002-7857-873X I. Susin

https://orcid.org/0000-0002-0724-7909 A.V. Pires

https://orcid.org/0000-0002-2210-7963

\begin{abstract}
Two experiments were conducted to evaluate the effect of thyme (Thymus vulgaris) essential oil (EO) doses on rumen fermentation, nutrient digestibility, and nitrogen metabolism, as well as performance and coccidia oocyst discharge. In experiment I, 20 rumen-cannulated wethers received the experimental diets containing $80 \%$ dry matter (DM) of haylage and $20 \%$ DM of concentrate. Treatments were $25 \mathrm{mg}$ of monensin $/ \mathrm{kg}$ DM or doses of $1.25,2.50$, or $3.75 \mathrm{~g}$ of thyme EO/kg DM. In experiment II, 50 ewe lambs received the same diets from experiment I, including a diet without feed additives. Wethers fed with diets containing $1.25 \mathrm{~g} / \mathrm{kg}$ DM of thyme EO had higher molar proportion of propionate $(\mathrm{P}=0.03)$ and butyrate $(\mathrm{P}<0.01)$, and lower $(\mathrm{P}=0.04)$ acetate to propionate ratio than other treatments. Adding thyme EO to diets increased $(\mathrm{P}=0.02)$ nitrogen retention compared to monensin. The performance of ewe lambs was not affected $(\mathrm{P} \geq 0.05)$ by treatments. However, lambs fed monensin had a lower $(\mathrm{P}=0.04)$ number of coccidia oocyst discharge than others. Adding $1.25 \mathrm{~g} / \mathrm{kg}$ DM of thyme EO in high-forage diet improved ruminal fermentation. Thyme EO enhanced nitrogen metabolism, however, it did not improve performance.
\end{abstract}

Keywords: coccidiosis, feed additives, forage, monensin, performance

\title{
RESUMO
}

Dois experimentos foram conduzidos para avaliar o efeito de doses de óleo essencial (OE) de tomilho (Thymus vulgaris) sobre a fermentação ruminal, a digestibilidade de nutrientes e o metabolismo de nitrogênio, bem como sobre o desempenho e a descarga de oocistos de coccídeos. No experimento I, 20 ovinos canulados receberam dietas experimentais contendo $80 \%$ de matéria seca (MS) de pré-secado e $20 \%$ de MS de concentrado. Os tratamentos foram 25mg de monensina/kg de MS ou doses de 1,25, 2,50 ou 3,75g de OE de tomilho/kg de MS. No experimento II, 50 borregas receberam as mesmas dietas do experimento I, incluindo uma dieta sem aditivos. Os animais alimentados com dietas contendo $1,25 \mathrm{~g}$ de $O E$ de tomilho apresentaram maior proporção molar de propionato $(P=0,03)$ e de butirato $(P<0,01) e$ menor $(P=0,04)$ relação acetato/propionato do que outros tratamentos. A adição de $O E$ de tomilho nas dietas aumentou $(P=0,02)$ a retenção de nitrogênio em comparação com a monensina. $O$ desempenho de cordeiros não foi afetado $(P \geq 0,05)$ pelos tratamentos. No entanto, cordeiros alimentados com monensina apresentaram menor $(P=0,04)$ número de oocistos de coccídeos. A adição de $1,25 \mathrm{~g} / \mathrm{kg}$ de $\mathrm{MS}$ de OE de tomilho na dieta forrageira melhorou o perfil da fermentação ruminal. $O$ OE de tomilho aumentou a retenção de nitrogênio, no entanto não melhorou o desempenho.

Palavras-chave: aditivos alimentares, coccidiose, forragem, monensina, performance

Recebido em 17 de maio de 2018

Aceito 24 de janeiro de 2019

E-mail: ferrazmvc@gmail.com 


\section{INTRODUCTION}

Ionophores are one of the most used feed additives for ruminants (Oliveira and Millen, 2014), however, the use of monensin as a growth promoter was banned in the European Union (OJEU, 2003), therefore, it is necessary to find substitutes from monensin, if it is also prohibited in Brazil. One alternative has been the essential oils (EO) that are aromatic compounds extracted from plants. Thyme EO was able to change the rumen microbial population (Cristani et al., 2007; Ultee et al., 2002; Juven et al., 1994), as well as decrease molar proportion of acetate and acetate to propionate (Ac:Prop) ratio, and increase the molar proportion of propionate in cattle fed high-concentrate diets (Vakili et al., 2013). Besides the EO rumen effects, these compounds may also present activity against intestinal parasites, such as coccidian or nematodes (Benchaar et al., 2008). Monensin is already used as coccidiostat for ruminants (Chartier and Paraud, 2012), preventing clinical coccidiosis.

The thymol is the main compound found in EO extracted from thymus plant (Thymus vulgaris; Table 1; Juven et al., 1994), which is able to inhibit gram-positive and gram-negative bacteria by decreasing enzyme activity and modifying membrane integrity (Juven et al., 1994). In the same line, p-cymene, another compound found in high concentration in thyme EO (Table 1), may diffuse through the plasma membrane into the bacterial cytoplasm (Cristani et al., 2007), causing expansion of the cell, allowing the passage of ions through the membrane (Ultee et al., 2002). Thus, this study aimed to determine the effects of thyme EO on rumen fermentation, nutrient digestibility, performance and coccidia oocyst discharge of the sheep fed with highforage diets.

\section{MATERIALS AND METHODS}

This study was carried out in the sheep research facilities at the Sheep and Goat Intensive Production System of the Department of Animal Science, Escola Superior de Agricultura "Luiz de Queiroz”, University of São Paulo. All animal procedures followed the guidelines recommended by the Animal Care and Use Committee at the same university (\# 4214031014).
Table 1. Chemical composition of thyme (Thymus vulgaris) essential oil used in experiments

\begin{tabular}{ll}
\hline Item & $\% \mathrm{DM}^{1}$ \\
\hline Thymol & 46.6 \\
p-cymene & 38.9 \\
Linalool & 3.8 \\
$\alpha$-pinene & 3.3 \\
Myrcene & 1.7 \\
1,8-cineole & 1.2 \\
Camphene & 1.0 \\
Limonene & 0.8 \\
$\beta$-pinene & 0.6 \\
$\gamma$-terpinene & 0.3 \\
Others & 1.8 \\
\hline
\end{tabular}

${ }^{1}$ DM: dry matter.

At the beginning of experiment I, twenty rumencannulated crossbred wethers ( $1 / 2$ Dorper $x \quad 1 / 2$ Santa Inês) were blocked according to initial body weight $(\mathrm{BW} ; 68.0 \pm 2.5 \mathrm{~kg}$ ) and randomly assigned to receive one of the following treatments (5 wethers/treatment): $25 \mathrm{mg}$ of monensin $/ \mathrm{kg}$ of dry matter (DM) (Rumensin ${ }^{\circledR} 100$, Elanco Brazil, São Paulo, SP, Brazil), or 1.25 (1.25EO), 2.50 (2.50EO) or 3.75 (3.75EO) $\mathrm{g}$ of thyme $\mathrm{EO} / \mathrm{kg} \mathrm{DM}$ (Tomilho Branco QT Timol ${ }^{\circledR}$, Laszlo Aromaterapia, Belo Horizonte, MG, Brazil).

Wethers were housed in individual pens containing feed bunks, mineral boxes and waterers. The diets were composed of $800 \mathrm{~g} / \mathrm{kg}$ DM of coastcross haylage and $200 \mathrm{~g} / \mathrm{kg}$ DM of concentrate (Table 2). On a daily basis, the concentrate was weighed using an electronic scale accurate to $0.1 \mathrm{~g}\left(\right.$ Marte $^{\circledR}$, AC $10 \mathrm{~K}$, São Paulo, SP, Brazil) and offered at 7:00 am. The haylage was weighed in the same scale and offered twice a day. Orts of each animal were weighed every morning in order to calculate DM intake (DMI). The orts were re-offered mixed to new haylage, to avoid changes in the relation between haylage and concentrate, and discarded once a week. The haylage was ground in a grinder without a sieve (Nogueira ${ }^{\circledR}$, DMP -4 , Itapira, São Paulo, Brazil), whereas the concentrate was mixed in a horizontal mixer (Lucato, Limeira, São Paulo, Brazil). The additives were mixed with concentrate at the time of feeding. 
Thyme essential oil...

Table 2. Proportions of ingredients and chemical composition of the experimental diets used in experiments

\begin{tabular}{|c|c|c|c|c|c|}
\hline \multirow{2}{*}{ Item } & \multicolumn{5}{|c|}{ Treatments $^{1}$} \\
\hline & CONT & MON & $1.25 \mathrm{EO}$ & $2.50 \mathrm{EO}$ & $3.75 \mathrm{EO}$ \\
\hline \multicolumn{6}{|l|}{ Ingredients (\% DM) } \\
\hline Coastcross haylage & 80 & 80 & 80 & 80 & 80 \\
\hline Ground corn & 12.0 & 12.0 & 11.9 & 11.7 & 11.6 \\
\hline Soybean meal & 4.5 & 4.5 & 4.5 & 4.5 & 4.5 \\
\hline Limestone & 1.0 & 1.0 & 1.0 & 1.0 & 1.0 \\
\hline Mineral mix ${ }^{2}$ & 2.5 & 2.5 & 2.5 & 2.5 & 2.5 \\
\hline Thyme essential oil & 0 & 0 & 0.125 & 0.250 & 0.375 \\
\hline \multicolumn{6}{|c|}{ Exp. I - Chemical composition (\% DM) } \\
\hline Dry matter (as-fed-basis) & & 56.8 & 56.7 & 56.8 & 56.7 \\
\hline Organic matter & & 87.7 & 87.7 & 87.7 & 87.4 \\
\hline Crude protein & & 14.0 & 14.0 & 14.2 & 14.3 \\
\hline Neutral detergent fiber & & 61.0 & 61.0 & 60.4 & 60.2 \\
\hline \multicolumn{6}{|c|}{ Exp. II - Chemical composition (\% DM) } \\
\hline Dry matter (as-fed-basis) & 65.8 & 65.8 & 65.8 & 65.8 & 65.8 \\
\hline Organic matter & 88.6 & 88.6 & 88.6 & 88.6 & 88.6 \\
\hline Crude protein & 13.4 & 13.4 & 13.9 & 13.9 & 14.2 \\
\hline Neutral detergent fiber & 60.7 & 60.7 & 60.9 & 60.7 & 60.3 \\
\hline
\end{tabular}

In experiment II, 50 ewe lambs $(1 / 2$ Dorper $x$ $1 / 2$ Santa Inês), aged approximately 150 days, were blocked according to initial $\mathrm{BW}(30.7 \pm 0.9 \mathrm{~kg})$, and assigned to receive one of the treatments previously described in Exp. I, including a negative control (CONT; no feed additive). Lambs were housed in individual pens with concrete floors, feed bunks, and waterers. The ratio of feed inclusion and chemical composition of diets are shown in Table 2, and the method of feeding and processing was similar to Exp. I.

Experiment I lasted 28 days, of which the first 23 days were used for diet adaptation and the last 5 days for sampling of feces and urine. The animals were kept in metabolism crates $(1.30 \times$ $0.55 \mathrm{~m}$ ) for metabolism trials that were fit with a feeding trough, drinking trough, and a system for collecting urine. The metabolism crates were kept in an indoor environment that was protected from rain and direct sunlight. The feces were collected using bags to avoid urine contamination, which was collected in plastic recipients containing $\mathrm{HCl}(6 N)$ to prevent ammonia volatilization. In addition, urine $\mathrm{pH}$ was measured twice a day to ensure that urine $\mathrm{pH}$ was below 3.0, avoiding ammonia volatilization. Fecal and urine production was collected twice a day. The 24-hour fecal and urine production was weighed using an electronic scale accurate to $0.1 \mathrm{~g}$, and $10 \%$ of daily feces and urine production were sampled and stored at $-18^{\circ} \mathrm{C}$ (wet weight). Subsequently, feces and urine samples were used to determine nutrient digestibility in the total digestive tract and nitrogen retention, respectively.

On the $7^{\text {th }}, 14^{\text {th }}, 21^{\text {st }}$ and $28^{\text {th }}$ days, $100 \mathrm{~mL}$ of ruminal fluid were collected at 0 (before feeding), 3, 6, 9 and 12 hours after the first feeding, to determine short chain fatty acids (SCFA) and ammonia-N. After collecting, ruminal fluid $\mathrm{pH}$ was measured with a digital potentiometer (Digimed ${ }^{\circledR}$, D20, Piracicaba, São Paulo, Brazil). The samples from each hour were pooled per day, resulting in one sample per animal per day, aiming to evaluate the effects of additive inclusion during the adaptation period $\left(7^{\text {th }}, 14^{\text {th }}\right.$ and $21^{\text {st }}$ days) and after the adaptation ( $28^{\text {th }}$ day).

Experiment II lasted 84 days, which was divided into three periods of 28 days each. The lambs were weighed after a 14-hour fast of feed on days $0,28^{\text {th }}, 56^{\text {th }}$ and $84^{\text {th }}$. At the end of each period, average daily gain (ADG) and feed efficiency $(\mathrm{FE}=\mathrm{ADG} / \mathrm{DMI})$ were calculated, considering the DMI average during each period. 
On the last day of each period, fecal samples were collected directly from the lambs' rectum on the last day of each period for oocyst discharge estimation by lambs under a natural coccidia infection. The oocysts were isolated from fecal samples by sucrose gradient flotation (Buret et al., 1990) in order to determine the number of coccidial oocysts. The samples were examined microscopically (Bel photonics ${ }^{\circledR}$, BIO2, Monza, Italy) using a McMaster chamber.

Samples of the offered feed, orts, and feces were thawed, compounded by animal per period, dried in a forced-air oven at $55^{\circ} \mathrm{C}$ for 72 hours and ground in a Wiley mill (Marconi ${ }^{\circledR}$, Piracicaba, SP, Brazil) passing a $1 \mathrm{~mm}$ screen. The DM content was determined by drying the samples at $105^{\circ} \mathrm{C}$ for 24 hours according to the method of the Association of Official Analytical Chemists (Official..., 1990; method \#934.01). Ash content was obtained by incinerating the samples in an oven at $600^{\circ} \mathrm{C}$ for 2 hours (method \#942.05; Official..., 1990). The organic matter content was calculated by the difference between the DM and ash $(\mathrm{OM}=100 \%$ of $\mathrm{DM}-\mathrm{ash} \%$ of $\mathrm{DM})$. Neutral detergent fiber was determined according to Van Soest et al. (1991) using $\alpha$ amylase and sodium sulfite in a 2000 Ankom $^{\circledR}$ system (Ankom Tech. Corp., Fairport, NY, USA). Total nitrogen of the offered feed, orts, feces, and urine was determined using Leco ${ }^{\circledR}$ FP528 instrument (Leco Corporation, St. Joseph, MI, USA; Official..., 1990; method \#968.0). Short chain fatty acid profile was determined according to Ferreira et al. (2016). The NH3-N concentration was determined with a colorimetric method that was described by Chaney and Marbach (1962), adapted for a microplate reader $\left(\mathrm{EON}^{\circledR}\right.$, BioTek Instruments, Winooski, VT, USA) with a 550nm absorbance filter.

Animals were used as the experimental unit for ANOVA analyses. The data for SCFA profile, ruminal $\mathrm{pH}$, ammonia (Exp. I), DMI, ADG, FE, and coccidia oocyst discharge (Exp. II) were analyzed as repeated measures over time. The statistical model used was $y_{i j k}=\mu+\mathrm{D}_{i}+b_{j}+e_{i j}+$ $\mathrm{T}_{k}+\mathrm{D}_{i} \mathrm{~T}_{k}+b_{j} \mathrm{~T}_{k}+e_{i j k}$, in which $\mu=$ overall mean, $\mathrm{D}_{i}=$ fixed effect of treatment, $b_{j}=$ random block effect, $e_{i j}=$ random error $\mathrm{A}, \mathrm{T}_{k}=$ fixed effect of time, $\mathrm{D}_{i} \mathrm{~T}_{k}=$ fixed effect of treatment $\times$ time interaction, $b_{j} \mathrm{~T}_{k}=$ random effect of block $\times$ time interaction, and $e_{i j k}=$ random error $\mathrm{B}$. All data analyzed as repeated measures were tested for the same covariance matrices used by Polizel et al. (2017), and the best covariance matrices was defined according to the lowest Akaike's Information Criterion value. The effect of treatment, day and interaction of treatment $\mathrm{x}$ day were defined by the $\mathrm{F}$ test $(\mathrm{P}<0.05)$ of variance analysis.

Nutrient intake and digestibility, variables related to $\mathrm{N}$ (Exp. I) and BW (Exp. II) were analyzed using the model $y_{i j}=\mu+\mathrm{D}_{i}+b_{j}+e_{i j}$, in which $\mu$ $=$ overall mean, $\mathrm{D}_{i}=$ fxed effect of diet, $b_{j}=$ random effect of block, and $e_{i j}=$ random error. The means were obtained by the LSMEANS command, whereas the treatment effect was defined by Tukey test $(\mathrm{P}<0.05)$. Before ANOVA by MIXED procedure (SAS version 9.0; SAS Inst. Inc., Cary, NC), data were analyzed by normality (Shapiro-Wilk) and homogeneity of variance (Levene) tests, and the data respected these statistics premises. In addition, there was no outliers (studentized residual $>3$ or $<-3$ ).

\section{RESULTS}

In experiment I, feed additives did not affect DMI $(\mathrm{P}=0.36)$, nutrient intake, total digestible nutrient intake $(\mathrm{P}=0.19)$, and nutrient digestibility coefficients ( $\mathrm{P}>0.05$; Table 3 ). There was $(\mathrm{P}<0.05)$ interaction between treatments and days on the molar proportion of propionate and butyrate, total SCFA concentration and Ac:Prop ratio (Table 4).

The molar proportion of propionate was higher $(\mathrm{P}<0.05)$ in monensin and 1.25EO treatments than in $2.50 \mathrm{EO}$ treatment on the $7^{\text {th }}$ and $14^{\text {th }}$ days. Moreover, wethers fed diets containing 1.25 of EO/kg DM had higher $(\mathrm{P}>0.01)$ molar proportion of butyrate compared to other treatments on the $7^{\text {th }}$ and $28^{\text {th }}$ days (Figure 1B). On the $28^{\text {th }}$ day, the $1.25 \mathrm{EO}$ treatment increased molar proportion of propionate $(\mathrm{P}=0.01)$ and decreased $(\mathrm{P}=0.04)$ Ac:Prop ratio and total SCFA $(\mathrm{P}<0.01)$ compared to others (Figure 1A, $\mathrm{C}$ and $\mathrm{D})$. 
Thyme essential oil...

Table 3. Nutrient intake and digestibility in wethers ( $1 / 2$ Dorper $x 1 / 2$ Santa Inês) fed high-forage diets from experiment I

\begin{tabular}{|c|c|c|c|c|c|c|}
\hline \multirow{2}{*}{ Item } & \multicolumn{4}{|c|}{ Treatments $^{1}$} & \multirow{2}{*}{$\mathrm{SEM}^{2}$} & \multirow{2}{*}{$p$ value } \\
\hline & MON & $1.25 \mathrm{EO}$ & $2.50 \mathrm{EO}$ & $3.75 \mathrm{EO}$ & & \\
\hline \multicolumn{7}{|l|}{ Intake $(\mathrm{kg} / \mathrm{d})$} \\
\hline Dry matter & 1.04 & 1.12 & 0.95 & 1.02 & 0.08 & 0.36 \\
\hline Organic matter & 0.91 & 0.99 & 0.83 & 0.89 & 0.07 & 0.36 \\
\hline Crude protein & 0.15 & 0.16 & 0.14 & 0.15 & 0.01 & 0.45 \\
\hline Neutral detergent fiber & 0.63 & 0.68 & 0.57 & 0.62 & 0.05 & 0.32 \\
\hline $\begin{array}{l}\text { Total digestible nutrient intake } \\
(\mathrm{kg} / \mathrm{d})\end{array}$ & 0.54 & 0.60 & 0.50 & 0.52 & 0.05 & 0.19 \\
\hline \multicolumn{7}{|c|}{ Total apparent digestibility coefficient } \\
\hline Dry matter & 0.52 & 0.53 & 0.53 & 0.51 & 0.02 & 0.86 \\
\hline Organic matter & 0.53 & 0.54 & 0.54 & 0.52 & 0.02 & 0.91 \\
\hline Crude protein & 0.69 & 0.69 & 0.67 & 0.67 & 0.01 & 0.66 \\
\hline Neutral detergent fiber & 0.51 & 0.51 & 0.51 & 0.48 & 0.02 & 0.87 \\
\hline
\end{tabular}

${ }^{1} \mathrm{MON}: 25 \mathrm{mg}$ of monensin/kg DM; $1.25 \mathrm{EO}: 1.25 \mathrm{~g}$ thyme EO/kg DM; 2.50EO: $2.50 \mathrm{~g}$ thyme EO/kg DM; 3.75EO: $3.75 \mathrm{~g}$ thyme $\mathrm{EO} / \mathrm{kg} \mathrm{DM}$.

${ }^{2}$ Standard error of the means.

Table 4. Ruminal levels of short chain fatty acids (SCFA), ammonia, and ruminal $\mathrm{pH}$ in wethers $(1 / 2$ Dorper $\mathrm{x} 1 / 2$ Santa Inês) fed high-forage diets from experiment I

\begin{tabular}{|c|c|c|c|c|c|c|c|c|}
\hline \multirow{2}{*}{ Item } & \multicolumn{4}{|c|}{ Treatments $^{1}$} & \multirow{2}{*}{$\mathrm{SEM}^{2}$} & \multicolumn{3}{|c|}{ p value ${ }^{3}$} \\
\hline & MON & $1.25 \mathrm{EO}$ & $2.50 \mathrm{EO}$ & $3.75 \mathrm{EO}$ & & $\mathrm{T}$ & $\mathrm{D}$ & $\mathrm{T} * \mathrm{D}$ \\
\hline \multicolumn{9}{|l|}{ SCFA (mM/100mM) } \\
\hline Acetate $(\mathrm{Ac})$ & 72.2 & 70.9 & 72.6 & 73.1 & 0.61 & 0.22 & 0.99 & 0.39 \\
\hline Propionate (Prop) & $15.6^{\mathrm{a}}$ & $15.6^{\mathrm{a}}$ & $14.5^{\mathrm{b}}$ & $14.8^{\mathrm{ab}}$ & 0.32 & 0.05 & 0.09 & 0.03 \\
\hline Isobutyrate & 1.10 & 1.12 & 1.19 & 1.11 & 0.06 & 0.69 & 0.02 & 0.06 \\
\hline Butyrate & $8.12^{\mathrm{b}}$ & $9.54^{\mathrm{a}}$ & $8.45^{\mathrm{b}}$ & $8.15^{\mathrm{b}}$ & 0.30 & 0.03 & $<0.01$ & $<0.01$ \\
\hline Isovalerate & 1.50 & 1.42 & 1.41 & 1.30 & 0.10 & 0.57 & 0.01 & 0.06 \\
\hline Valerate & 0.69 & 0.77 & 0.81 & 0.77 & 0.03 & 0.07 & 0.27 & 0.83 \\
\hline Ac:Prop ratio & $4.61^{\mathrm{a}}$ & $4.59^{\mathrm{a}}$ & $5.04^{\mathrm{b}}$ & $4.96^{\mathrm{ab}}$ & 0.13 & 0.04 & 0.23 & 0.04 \\
\hline Total SCFA (mM/L) & 91.1 & 87.8 & 93.5 & 97.1 & 3.30 & 0.21 & $<0.01$ & $<0.01$ \\
\hline Ammonia (mg/dL) & 9.12 & 8.56 & 10.1 & 10.1 & 1.25 & 0.79 & 0.04 & 0.95 \\
\hline $\mathrm{pH}$ & 6.51 & 6.61 & 6.56 & 6.47 & 0.05 & 0.14 & $<0.01$ & 0.12 \\
\hline
\end{tabular}

${ }^{1}$ MON: $25 \mathrm{mg}$ of monensin/kg DM; $1.25 \mathrm{EO}: 1.25 \mathrm{~g}$ thyme EO/kg DM; $2.50 \mathrm{EO}: 2.50 \mathrm{~g}$ thyme EO/kg DM; 3.75EO: $3.75 \mathrm{~g}$ thyme $\mathrm{EO} / \mathrm{kg} \mathrm{DM}$.

${ }^{2}$ Standard error of the means.

${ }^{3} \mathrm{~T}$ : fixed effect of treatment; D: fixed effect of day (samples of ruminal fluid were collected on the $7^{\text {th }}, 14^{\text {th }}, 21^{\text {st }}$ and $28^{\text {th }}$ days of each period); $\times \mathrm{D}$ : fixed effect of treatment $\times$ day interaction. Within a row, mean values with different superscript differ significantly $(\mathrm{P}<0.05)$.

No treatment effects were observed on nitrogen intake $(\mathrm{P}=0.45)$ and fecal excretion $(\mathrm{P}=0.86$; Table 5). However, wethers fed with monensin had higher $(\mathrm{P}=0.02)$ nitrogen excretion in urine than wethers fed with diets containing thyme EO, regardless of the dosage. Consequently, the addition of monensin in the diet resulted in lower nitrogen retention $(\mathrm{P}=0.02)$ than in diets containing thyme EO. In experiment II, the treatments did not affect final $\mathrm{BW}(\mathrm{P}=0.25)$, ADG $(\mathrm{P}=0.25)$, DMI $(\mathrm{P}=0.59$ and $\mathrm{P}=0.81$ for $\mathrm{g} / \mathrm{d}$ and $\mathrm{kg} / 100 \mathrm{~kg} \mathrm{BW}$, respectively), and $\mathrm{FE}(\mathrm{P}=$
0.21 ; Table 6). Nonetheless, ewe lambs fed with diets containing monensin had less $(\mathrm{P}=0.04)$ coccidia oocyst discharge compared to the negative control and doses of thyme EO.

During the adaptation to the diets (period 1), lambs had reduced $(\mathrm{P}=0.05)$ ADG compared to periods 2 and $3(56.05$ vs 87.53 and $77.70 \mathrm{~g}$, respectively), whose DMI $(\mathrm{P}<0.01 \mathrm{~g} / \mathrm{d}$ and $\mathrm{kg} / 100 \mathrm{~kg} \mathrm{BW})$ increased along the time (782.1, 974.6 and $1046.0 \mathrm{~g} / \mathrm{d} ; 2.52,2.94$ and $2.98 \%$ of BW for periods 1,2 and 3 , respectively). 
Similarly, the number of coccidia oocyst discharge increased $(\mathrm{P}<0.01)$ from the second to the third period (4.76 vs 22.95, respectively).

\section{DISCUSSION}

This study aimed to evaluate whether adding thyme EO in sheep diets changes the rumen fermentation process, improving animal performance as occurs with monensin use. The results demonstrated that molar proportion of propionate and the Ac:Prop ratio obtained from $1.25 \mathrm{EO}$ treatment were the highest on the $28^{\text {th }}$ day (after adaptation period) when compared to other treatments, suggesting that this dose of thyme EO can improve rumen fermentation. The great advantage of monensin use in ruminant diets is its capacity in increasing molar proportion of propionate (Ellis et al., 2012). Therefore, identifying a dosage of thyme EO that demonstrates better results on rumen fermentation compared to monensin means a great potential for using this additive. On the other hand, the use of thyme EO in high doses resulted in lower molar proportion of propionate, which could be explained by toxic effect of thyme EO on gram-negative bacteria (Nazzaro et al., 2013).
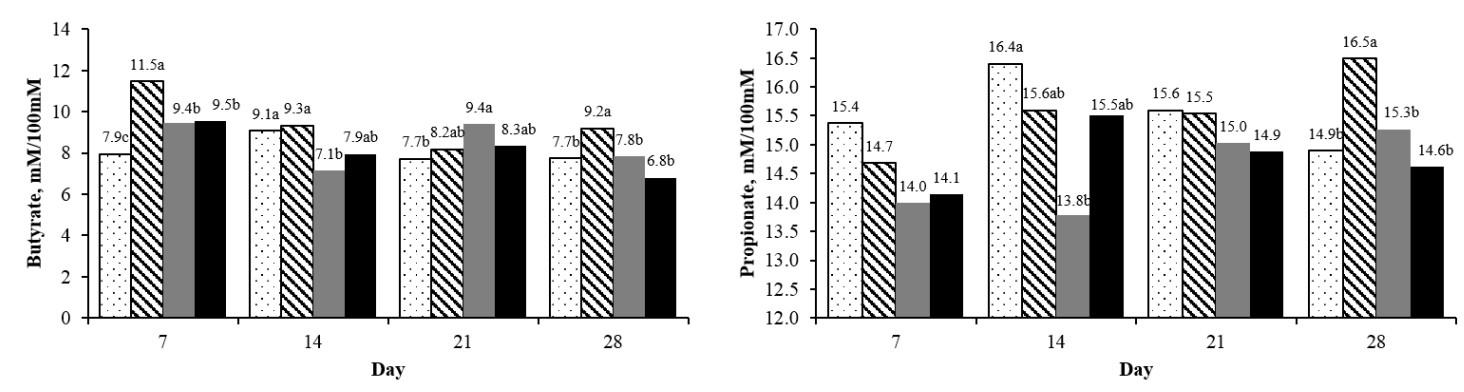

$\square \mathrm{MON} \quad \mathbf{\mathbf { N }} 1.25 \mathrm{OE}=2.500 \mathrm{E} \quad \mathbf{m} .75 \mathrm{OE}$
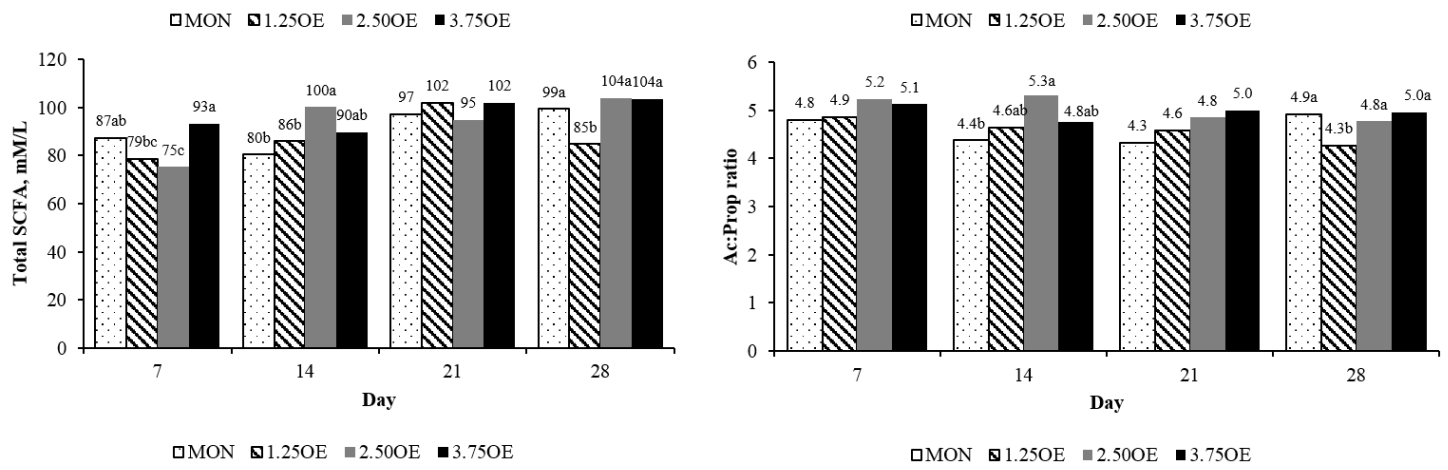

Figure 1. Description of interaction effects between treatments and days for molar proportion of propionate (A) and butyrate (B), total short chain fatty acids (SCFA; C) concentration, and acetate to propionate (Ac:Prop; D) ratio. Treatments - MON: $25 \mathrm{mg}$ of monensin/kg DM; $1.25 \mathrm{EO}: 1.25 \mathrm{~g}$ thyme EO/kg DM; 2.50EO: $2.50 \mathrm{~g}$ thyme EO/kg DM; 3.75EO: $3.75 \mathrm{~g}$ thyme EO/kg DM. T: fixed effect of treatment; D: fixed effect of day (samples of ruminal fluid were collected on the $7^{\text {th }}, 14^{\text {th }}, 21^{\text {st }}$ and $28^{\text {th }}$ days of each period); T $\times D$ : fixed effect of treatment $\times$ day interaction. Mean followed by different letters differ significantly $(\mathrm{P}<0.05)$.

Table 5. Nitrogen balance in wethers (1/2 Dorper x $1 / 2$ Santa Inês) fed high-forage diets from experiment I

\begin{tabular}{lllllll}
\hline \multirow{2}{*}{ Item } & \multicolumn{3}{l}{ Treatments } & \multirow{2}{*}{ SEM $^{2}$} & $p$ value \\
\cline { 2 - 5 } & MON & $1.25 \mathrm{EO}$ & $2.50 \mathrm{EO}$ & $3.75 \mathrm{EO}$ & & 0.45 \\
$\mathrm{~N}$ intake $(\mathrm{g} / \mathrm{d})$ & 23.2 & 25.2 & 21.6 & 23.3 & 1.77 & 0.86 \\
Fecal N (g/d) & 7.23 & 7.92 & 7.37 & 7.71 & 0.69 & 0.86 \\
Urinary N (g/d) & $8.72^{\mathrm{a}}$ & $4.79^{\mathrm{b}}$ & $4.62^{\mathrm{b}}$ & $3.54^{\mathrm{b}}$ & 1.09 & 0.02 \\
$\mathrm{~N}$ retention (g/d) & $7.2^{\mathrm{b}}$ & $12.8^{\mathrm{a}}$ & $10.5^{\mathrm{a}}$ & $12.2^{\mathrm{a}}$ & 1.24 & 0.02 \\
\hline
\end{tabular}

${ }^{1}$ MON: 25mg of monensin/kg DM; 1.25EO: 1.25g thyme EO/kg DM; 2.50EO: 2.50g thyme EO/kg DM; 3.75EO: $3.75 \mathrm{~g}$ thyme $\mathrm{EO} / \mathrm{kg} \mathrm{DM}$.

${ }^{2}$ Standard error of the means. 
Thyme essential oil...

Table 6. Performance of ewe lambs ( $1 / 2$ Dorper x $1 / 2$ Santa Inês) fed high-forage diets from experiment II

\begin{tabular}{|c|c|c|c|c|c|c|c|c|c|}
\hline \multirow{2}{*}{ Item $\S$} & \multicolumn{5}{|c|}{ Treatments $^{1}$} & \multirow{2}{*}{$\mathrm{SEM}^{2}$} & \multicolumn{3}{|c|}{$p$ value $^{3}$} \\
\hline & CONT & MON & $1.25 \mathrm{EO}$ & $2.50 \mathrm{EO}$ & $3.75 \mathrm{EO}$ & & $\mathrm{T}$ & $\mathrm{D}$ & $\mathrm{T} \times \mathrm{D}$ \\
\hline \multicolumn{10}{|l|}{$\mathrm{BW}(\mathrm{kg})$} \\
\hline Initial & 31.0 & 30.9 & 30.2 & 30.1 & 30.9 & 0.89 & 0.20 & - & - \\
\hline Final P1 & 31.3 & 33.1 & 31.5 & 32.0 & 32.9 & 1.19 & 0.17 & - & - \\
\hline Final P2 & 34.0 & 36.0 & 33.5 & 34.4 & 34.9 & 1.04 & 0.06 & - & - \\
\hline Final P3 & 36.1 & 38.1 & 35.8 & 36.8 & 36.7 & 1.06 & 0.25 & - & - \\
\hline $\operatorname{ADG}(g)$ & 60.0 & 86.3 & 69.2 & 80.5 & 71.9 & 8.67 & 0.25 & 0.05 & 0.36 \\
\hline \multicolumn{10}{|l|}{ DMI, } \\
\hline $\mathrm{g} / \mathrm{d}$ & 930 & 972 & 912 & 932 & 922 & 28.4 & 0.59 & $<.01$ & 0.37 \\
\hline$\%$ of BW & 2.85 & 2.82 & 2.81 & 2.83 & 2.73 & 0.09 & 0.81 & $<.01$ & 0.53 \\
\hline $\mathrm{FE}$ & 0.06 & 0.09 & 0.08 & 0.08 & 0.08 & 0.01 & 0.21 & 0.15 & 0.43 \\
\hline Coccidia $^{4}$ & $17.6^{\mathrm{b}}$ & $2.0^{\mathrm{a}}$ & $14.5^{\mathrm{b}}$ & $17.2^{\mathrm{b}}$ & $17.9^{\mathrm{b}}$ & 4.07 & 0.04 & $<.01$ & 0.18 \\
\hline
\end{tabular}

${ }^{1}$ CONT: no additive diet; MON: $25 \mathrm{mg}$ of monensin/kg DM; 1.25EO: 1.25g thyme EO/kg DM; 2.50EO: $2.50 \mathrm{~g}$ thyme EO/kg DM; 3.75EO: $3.75 \mathrm{~g}$ thyme EO/kg DM.

${ }^{2}$ Standard error of the means.

${ }^{3}$ T: fixed effect of treatment; D: fixed effect of day (lambs were weighed on days $0,28^{\text {th }}, 56^{\text {th }}$ and $84^{\text {th }}$ of experiment); $\mathrm{T} \times \mathrm{D}$ : fixed effect of treatment $\times$ day interaction. Within a row, mean values with different superscript differ significantly $(\mathrm{P}<0.05)$.

${ }^{4}$ Coccidia oocyst discharge per gram of faces.

$\mathrm{BW}$ : body weight; $\mathrm{ADG}$ : average daily gain; $\mathrm{DMI}=$ dry matter intake; $\mathrm{FE}=$ feed efficiency $(\mathrm{kg}$ of $\mathrm{BW}$ gain $/ \mathrm{kg}$ of feed).

The 1.25EO treatment also increased the molar proportion of butyrate, suggesting that thyme EO did not inhibit butyrate production during fermentation. In the same line to this finding, several authors reported that high doses of EO increased butyrate proportion (Ramos-Morales et al., 2013). On the other hand, Ellis et al. (2012) reported a decrease in the molar proportion of butyrate when monensin was used, mainly in high forage diets. In addition, the 1.25EO also decreased the SCFA concentration on the $28^{\text {th }}$ day of experiment, indicating that this dose of EO may decrease the fermentation rate or increase disappearance of SCFA in the rumen. However, the effects of EO on ruminal fermentation have been extremely variable (Calsamiglia et al., 2006), which may also be observed in results during the adaptation period. The interaction between treatments and days observed in molar proportion of propionate, butyrate and total SCFA indicate that the responses was dosage dependent, as well as the time of supplementation with additives. Thus, the molar proportion of SCFAs evaluated in this study had different results during the adaptation period, suggesting the use of doses throughout the production stages. In addition, there are few studies evaluating the effect of feed additives on rumen metabolism during the adaptation period, further research is necessary to elucidate what occurs during this period.

The monensin and thyme EO doses resulted in similar ruminal ammonia concentration, and a remarkable effect of monensin and thyme $\mathrm{EO}$ on ruminal ammonia concentration is described in the literature. Hassanat and Benchaar, (2013) reported that monensin decreased ruminal ammonia concentration in vitro study by decreasing the deamination of amino acids (Russell and Strobel, 1988). Russell and Strobel (1988) found that a group of gram-positive bacteria, which are monensin-sensitive, called hyperammonia-producing bacteria, had high specific activity for ammonia production. In the same line, some in vitro experiments have demonstrated a reduction in ammonia concentration when thyme EO was added (Castillejos et al., 2008). The thyme EO can interact with microbial cell membranes and inhibit the growth of some bacteria, resulting in lower ammonia concentration (Calsamiglia et al., 2007). Although the thyme EO did not affect ammonia concentration on rumen compared to monensin, the addition of thyme EO on diets increased the $\mathrm{N}$ retention by decreasing urinary $\mathrm{N}$ excretion. Rajabi et al. (2017) observed the similar effect on urinary $\mathrm{N}$ and balance when used pomegranate peel extract; however, the 
exact mechanism for positive nitrogen balance is yet not clear. In addition, it is important to highlight that thyme EO, overall, was able to decrease $\mathrm{N}$ excretion without decreasing the $\mathrm{N}$ level in the diet, which may reduce environmental pollution by $\mathrm{N}$.

Possibly, the main effect of EO in the feed digestion is the reduction of protein and starch degradation, as reviewed by Patra (2011). In this study, no treatment effects of thyme EO were observed in nutrient digestibility, whose diet was composed mainly of tropical grass. There are few studies evaluating the effect of thyme EO in tropical grass digestibility, but Kouazounde et $a l .$, (2015) observed a decrease in digestibility of tropical grass using EO containing thymol in in vitro experiment. In addition, the diets used in the current research had $80 \% \mathrm{DM}$ of forage, containing $60 \% \mathrm{DM}$ of neutral detergent fiber, which results in a physical limitation intake. The literature is scarce concerning forage quality impact in the relation between DMI and additives used in high forage diets, precluding the establishment of the relation among forage quality, DMI and additives.

There is no consensus whether thyme EO changes palatability of feed intake, however, many researches have established that EO utilization in ruminant diet did not affect the DMI (Benchaar et al., 2007), corroborating with the results from this work. On the other hand, some authors reported that EO could stimulate DMI (Fandiño et al., 2008). Moreover, the answers regarding the EO use in ruminant diets depended on dosage, showing differences according to its amount in the diet (Yang et al., 2010). Therefore, the discrimination among the EO types and mainly their composition, which may result in changes to physiological processes, ruminal fermentation, nutrient digestibility, as well as issues related to sensory, such as flavor, odor, and acceptability are important. Furthermore, we observed that even adding the total amount of thyme EO or monensin in concentrate, which represented only $20 \%$ of the diet, did not result in a negative impact on concentrate intake in both experiments.
Despite the changes observed on ruminal fermentation and nitrogen balance in experiment I, there was no difference in lambs' performance in experiment II. However, lambs feeding diets containing monensin had decreased coccidia oocyst discharge compared to lambs fed with thyme EO or no additive. Perhaps the potential effect of thyme EO as a manipulator of ruminal fermentation was not expressed because of the infestation of coccidia in lambs, which did not occur with lambs feeding monensin, an efficient coccidiostat for ruminants (Chartier and Paraud, 2012). Clinical coccidiosis occurs when lambs are submitted to physiological stress (Chartier and Paraud, 2012). Although an infestation occurs, clinical signs may be absent, but a lower BW gain is common (Andrews, 2013), which probably occurred during the adaptation period because the concentration ratio in the diet changed from $50 \%$ to $20 \%$. This was confirmed by lower ADG and DMI in the first period, reflecting in an increase of coccidia oocyst discharge in period 3 . The EO compounds may also present activity against intestinal parasites, such as coccidian or nematodes (Benchaar et al., 2008). However, EO effectiveness against such parasites in the lower digestive tract may depend on the antimicrobial components' capacity to remain active after passage through the rumen (Benchaar et al., 2008) and abomasum, which probably did not occur in this study.

\section{CONCLUSION}

Adding $1.25 \mathrm{~g} / \mathrm{kg}$ DM of thyme EO to highforage diet improved ruminal fermentation on the $28^{\text {th }}$ day. In addition, thyme EO improved nitrogen metabolism compared to monensin. However, thyme EO did not improve performance, nor prevent coccidiosis in lambs.

\section{ACKNOWLEDGMENTS}

The authors thank the Fundação de Amparo à Pesquisa do Estado de São Paulo (FAPESP) and Conselho Nacional de Desenvolvimento Científico e Tecnológico ( $\mathrm{CNPq}$ ) for financial support. 


\section{REFERENCES}

ANDREWS, A.H. Some aspects of coccidiosis in sheep and goats. Small Ruminants Res. v.110, p.93-95, 2013.

BENCHAAR, C.; CALSAMIGLIA, S.; CHAVES, A. V. et al. A review of plant-derived essential oils in ruminant nutrition and production. Anim. Feed Sci. Technol. v.145, p.209-228, 2008.

BENCHAAR, C.; PETIT, H.V.; OUELLET, D.R. et al. Effects of essential oils on digestion, ruminal fermentation, rumen microbial populations, milk production, and milk composition in dairy cows fed alfalfa silage or corn silage J. Dairy Sci. v.90, p.886-897, 2007.

BURET, A.; GALL, D.G.; NATION, P.N. et al. Intestinal protozoa and epithelial cell kinetics, structure and function. Parasitol. Today, v.6, p.375-380, 1990.

CALSAMIGLIA, S.; BUSQUET, M.; CARDOZO, P.W. et al. Essential oils as modifiers of rumen microbial fermentation. $J$. Dairy Sci., v.90, p.2580-2595, 2006.

CALSAMIGLIA, S.; BUSQUET, M.; CARDOZO, P.W. et al. Invited review: essential oils as modifiers of rumen microbial fermentation. J. Dairy Sci., v.90, p.2580-2595, 2007.

CASTILLEJOS, L.; CALSAMIGLIA, S.; MARÍN-TERESO, J. et al. In vitro evaluation of effects of ten essential oils at three doses on ruminal fermentation of high concentrate feedlottype diets. Anim. Feed Sci. Technol., v.145, p.259-270, 2008.

CHANEY, A.L.; MARBACH. E.P. Modified reagents for determination of urea and ammonia. Clin. Chem., v.8, p.130-132, 1962.

CHARTIER, C.; PARAUD, C. Coccidiosis due to Eimeria in sheep and goats, a review. Small Ruminant Res., v.103, p.84-92, 2012.

COMMISSION Regulation (EC), 2003. N. $1831 / 2003$ of the European parliament and the council of 22 September 2003. On additives for use in animal nutrition. Off. J. Eur. Union, L268, p.29-43, 2003. COMMISSION
CRISTANI, M.; D'ARRIGO, M.; MANDALARI, G. et al. Interaction of four monoterpenes contained in essential oils with model membranes: Implications for their antibacterial activity. J. Agric. Food Chem., v.55, p.6300-6308, 2007.

ELLIS, J.L.; DIJKSTRA, J.; BANNINK, A. et al. Quantifying the effect of monensin dose on the rumen volatile fatty acid profile in highgrain-fed beef cattle. J. Anim. Sci., v.90, p.27172726, 2012.

FANDIÑO, I.; CALSAMIGLIA, S.; FERRET, A. et al. Anise and capsicum as alternatives to monensin to modify rumen fermentation in beef heifers fed a high concentrate diet. Anim. Feed Sci. Technol., v.145, p.409-417, 2008.

FERREIRA, E.M.; PIRES, A.V.; SUSIN, I. et al. Nutrient digestibility and ruminal fatty acid metabolism in lambs supplemented with soybean oil partially replaced by fish oil blend. Anim. Feed Sci. Technol., v.216, p.30-39, 2016.

HASSANAT, F.; BENCHAAR, C. Assessment of the effect of condensed (acacia and quebracho) and hydrolysable (chestnut and valonea) tannins on rumen fermentation and methane production in vitro. J. Sci. Food Agric., v.93, p.332-339, 2013.

JUVEN, B.J.; KANNER, J.; SCHVED, F. et al. Factors that interact with the antibacterial action of thyme essential oil and its active constituents. J. Appl. Bacteriol., v.76, p.626-631, 1994.

KOUAZOUNDE, J.B.; JIN, L.; ASSOGBA, F.M. et al. Effects of essential oils from medicinal plants acclimated to Benin on in vitro ruminal fermentation of Andropogon gayanus grass. J. Sci. Food Agric., v.95, p.1031-1038, 2015.

NAZZARO, F.; FRATIANNI, F.; MARTINO, L. et al. Effect of essential oils on pathogenic bacteria. Pharmaceuticals, v.6, p.1451-1474, 2013.

OFFICIAL methods of analysis of the association of official analytical chemists. 15.ed. Arlington, VA: AOAC International, 1990.

OLIVEIRA, C.A.; MILLEN, D.D. Survey of the nutritional recommendations and management practices adopted by feedlot cattle nutritionists in Brazil. Anim. Feed Sci. Technol., v.197, p.64-75, 2014. 
PATRA, A.K. Effects of essential oils on rumen fermentation, microbial ecology and ruminant production. Asian J. Anim. Vet. Adv., v.6, p.416428, 2011.

POLIZEL, D.M.; SUSIN, I.; GENTIL, R.S. et al. Crude glycerin decreases nonesterifed fatty acid concentration in ewes during late gestation and early lactation. J. Anim. Sci., v.95, p.875-883, 2017.

RAJABI, M.; ROUZBEHAN, Y.; REZAEIA J. A strategy to improve nitrogen utilization, reduce environmental impact, and increase performance and antioxidant capacity of fattening lambs using pomegranate peel extract. J. Anim. Sci., v.95, p.499-510, 2017.

RAMOS-MORALES, E.; MARTÍNEZFERNÁNDEZ, G.; ABECIA, L. et al. Garlic derived compounds modify ruminal fatty acid biohydrogenation and induce shifts in the butyrivibrio community in continuous-culture fermenters. Anim. Feed Sci. Technol., v.184, p.38-48, 2013.

RUSSELL, J.B.; STROBEL, H.J. Effects of additives on in vitro ruminal fermentation: a comparison of monensin and bacitracin, another Gram-positive antibiotic. J. Anim. Sci., v.66, p.552-558, 1988.
ULTEE, A.; BENNIK, M.H.J.; MOEZELAAR, $\mathrm{R}$. The phenolic hydroxyl group of carvacrol is essential for action against the food-borne pathogen Bacillus cereus. Appl. Environ. Microbiol., v.68, p.1561-1568, 2002.

VAKILI, A.R.; KHORRAMI, B.; MESGARAN, M.D. et al. The effects of thyme and cinnamon essential oils on performance, rumen fermentation and blood metabolites in Holstein calves consuming high concentrate diet. AsianAustralas. J. Anim. Sci., v.26, p.935-944, 2013.

VAN SOEST, P.J.; ROBERTSON, J.B.; LEWIS, B.A. Methods for dietary fiber, neutral detergent fiber, and nonstarch polysaccharides in relation to animal nutrition. J. Dairy Sci., v.74, p.35833597, 1991.

YANG, W.Z.; AMETAJ, B.N.; BENCHAAR, C. et al. Dose response to cinnamaldehyde supplementation in growing beef heifers: ruminal and intestinal digestion. J. Anim. Sci., v.88, p.680-688, 2010. 